\title{
The Use of Social Media by Prospective Teachers and Their Practice Aims of Web Technologies in Turkey
}

\author{
Halük Ünsal \\ Gazi Educational Faculty, Gazi University, Ankara, Turkey
}

Copyright $(2018$ by authors, all rights reserved. Authors agree that this article remains permanently open access under the terms of the Creative Commons Attribution License 4.0 International License

\begin{abstract}
The purpose of this research is to find out prospective teachers' use of social media tools and their practice aim of web technologies. The research was prepared in survey model. Convenience sampling technique was used in the research. The sample of the research is composed of 61 prospective elementary teachers from education faculty of a state university, and 53 prospective teachers in the Department of Computer and Instructional Technology (CEIT). The data collection tool is social media and web technology usage scale which is developed by the researcher. This scale consists parts of using social media and web technologies. The first part of this scale consists of terms about social media tools and the other part consists of information about usage of web technologies. At the end of the research, it was concluded that prospective teachers always use YouTube and Instagram as readers and also other social media tools such as WhatsApp application. However, it has been found that prospective teachers tend to use Web technologies very much in their daily work, lessons and entertainment at sub-dimensions. It is advisable to carry out studies related to different science and different departments except for the prospective teachers regarding the usage of web technology.
\end{abstract}

Keywords Social Media, Web Technology, Use of Web Technology, Prospective Teachers

\section{Introduction}

Lifestyles have changed steadily over the last hundred years and certainly within the last ten years [1]. This rapid global change and developments in the technology are also directly affecting the education and training services. In particular, advances in the internet and web technologies are bringing about change and transformation in all staff involved in the training process and in all levels of education.

It is stated as the digital natives, born and raised within today's technology, are made up of individuals who can use all kinds of technological tools at a good level and who live in a technologically intensive body and mental process [2]. This should be taken into account during training, education and communication which are carried out with these individuals today.

Thanks to new technologies, because of their advantages and ease of use, all individuals are use them both widely and frequently. At the same time, these technological developments will affect all stakeholders (academics, managers, teachers, students, parents and others) who are involved in education. The integration of technology into the field of education aims to improve and enhance the education and training environments of these technologies. All elements of education must be included in the work to reach the intended goals [3].

Teacher and prospective teachers are among the most important elements in the education system. It is important to carry out studies that take into account the training of teachers and their integration to technologies in the field of education. According to Baran \& Ata [4], the strength of the emerging technologies at educational environment depends on handling socio-economic and socio-cultural elements together. In this context, education and new technologies should be integrated with cultural structure, economic level and social values.

\section{Social Media}

According to Baruah [5], social media means the use of mobile and web-based technologies to transform the interactive communication into the interactive dialogue. There are many different forms of social media. For example, magazines, internet forums, weblogs, social blogs, microblogs, wikis, podcasts, photos or pictures, video rating and social bookmark etc. Since the world is in the midst of a social media revolution, social media tools such as Facebook, Twitter, Orkut, Myspace, Skype etc. are widely used for communicational purposes. This communication can be in the form of a person or a group. At the same time, social media is an environment for social interaction as a higher level beyond social communication.

From another dimension social media can be said to be 
users' contributions that are usually very short, made through web-based technologies, streamed to events such as status updates or comments. Social media is categorized according to various categories. They are used for communication (Blog, Twitter, etc.), cooperation (Vikia, Skype etc.), multimedia (Picasa, Secondlife, etc.) [6].

Especially the acceleration, expansion and increase of the accession of the internet and the increase of the usage of social media tools affect all the people in the world. Communication, cooperation, sharing and intense interaction among individuals in the social media environments clearly demonstrate the power and importance of social media.

New social networking nets have evolved from Web 1.0 to Web 2.0. Web 2.0, a technological transition, is a technology that changes the web, and people do not only download something in the consumer role on this participatory platform, but also contribute new contents by loading to it [7].

Social media, which are conceptualized as Web 2.0 technologies and dynamic web tools, seem to be very important today. It is understood that all users are able to communicate, share, and collaborate on the basis of various means. According to Özmen, Aküzüm, Sünkür \& Baysal, [8], social media changes some behaviors and habits of individuals in society. Social media supports individuals to develop skills such as being more active, creativity, cooperation, interaction, communication, research and problem solving.

Web 2.0 technologies are widely used by students at both universities and schools. For this reason, the teaching strategies and substructure of educational institutions should be able to adapt to this situation at the highest level. Both universities and schools have to support the use of Web 2.0 tools by students [9]. It increases the academic achievement and motivation of students in collaborative learning environments by using dynamic web Technologies [10]. Teachers have stated that the use of dynamic web technologies has many positive outcomes.

The intensive use of Web 2.0 tools in social media causes the learning and teaching activities and activities of teachers and academicians to take place in this environment. There are plenty of opportunities and opportunities for both classroom and non-classroom activities to be designed in this environment. However, teachers and academics should pay attention to the content created by open users in the web environment. Through these contents, students should be helped for critical thinking. According to Relan \& Gillani [11], web-based instruction encourages learning by living and thus the learning process takes place in relation to the real world.

\section{Using Web Technologies}

The internet and web technologies have passed through many stages until today, at first to two computers connected to network structure in the United States in 1965 and then the first international connection application called Arpanet came into being in 1973 [12]. Today, it is not an ambitious idea to suggest that internet and web technologies are the basis of great changes and developments.

Web technology is an essential tool in all areas as well as in education. Web technology is a very effective learning environment, especially for educational institutions. In this context, it is possible to save time and cut the cost for both individual learning and organizational learning, providing active, deep learning and also thinking skills, cooperative support, flexible and detailed learning opportunities, own pace learning as well as being independent [13].

In addition, web-based learning environments provide many benefits such as interactive learning, versatile communication, highly synthesized knowledge, space and time independence, sharing, and repeatability. It is hoped that 3 billion people in the world and 30 million people in our country have access to the internet and web Technologies, therefore they can benefit from the learning and other possibilities that the web environment offers. For this reason, web technologies need to be used in a positive way in education [12].

Yalın [14], emphasizes that the computer / internet can be used for teaching, production and communication purposes. Secondly, it can be said that individuals can use these technologies for production in lessons and extracurricular works, and thirdly, individuals can use them for sharing information, communication, and discussion. According to Dillon \& Zhu [15], www and web-based teaching is a great communication system on the internet. Many www pages provide an informal teaching environment. People use information provided by various organizational sources on these pages. Web sites are not educational in a sense, but are actually sources of information.

Considering the studies related to social media and web technology; [16], the use of social media by college students [17], the use of Web 2.0 technologies [18], the use of information technologies by primary school teachers, teachers' use of information technology [19], the use of web-based language teaching systems in the foreign language teaching process [20], and the use of technology in higher education [21]. However, research on social media and web technology usage is limited. With this research, it has been tried to reveal the aims of prospective teachers' use of social media and web technology.

It is hoped that the researches and their results about using social media and web technologies will be important because the field of education and its stakeholders are very wide and the number of affected individuals are higher.

\section{The Aim of the Study}

The aim of this research is to determine prospective teachers' use of social media tools and their purposes of using web Technologies. In response to this aim, the 
following questions were tried to be answered:

1. What is the situation for the prospective teachers' use of social media tools?

2. How are the prospective teachers' using web technologies?

3. Are the aims of the prospective teachers using web technologies different from each other?

4. Are the aims of the prospective teachers different from class to class using web technologies?

\section{Method}

\section{The Model of the Study}

This research is in screening model. The screening model can be explained as a model which is used to reveal the current situation [22]. Here, it is tried to explain prospective teachers' situation of using web technologies in real life.

\section{Population and Sample}

Convenience sampling technique from purpose sampling method has been used in the research [23]. The sample of the research is composed of 61 prospective elementary teachers from education faculty of a state university; 30 prospective teachers from the first class and 31 prospective teachers from the third class participated in the study and 53 teachers from Computer and Instructional Technology Education (CITE) department.30 prospective teacher from the first grade and 23 prospective teachers from the third grade attended from education faculty.

\section{Data Collection Tools and Data Analysis}

The data collection tool is social media and web technology usage scale developed by the researcher. The first part of this scale consists of terms about social media tools and the other part consists of information about usage of web technologies. Scale items were prepared as likert type scales in the form of 5 (always), 4 (often), 3 (sometimes), 2 (rarely) and 1 (never). In the process of developing the scale, two field experts and a survey evaluation expert were consulted and the validity of the opinions was improved by making corrections. For the reliability of the scale, factor structures and reliability co-efficient were calculated. At the end of the validity and reliability studies, two items were removed from the 31 -item scale and the last item of 29 items was taken. The factors resulting from the scale, factor analysis and varimax rotation are named as "daily jobs", "entertainment", "work", "development" and "course" and consists of five sub-factors. The scale explains $52 \%$ of the total variance. The first factor explained $12 \%$ of total variance, $12 \%$ of the second factor, $11 \%$ of the third factor, $10 \%$ of the fourth factor and $7 \%$ of the fifth factor.

Item numbers, factor loadings and sub-factors in the measurement are 1, 2, 3, 4, 5, 7, 8 and 27 items (daily works), 12, 24, 25 and 26 items (entertainment) and 6, 23, 28 and 29 items (business), 10, 11, 19, 20, 21 and 22 items (development) 9, 13, 14, 15, 16, 17, and 18 items (courses) were identified in turns as the second and third substances.

Factor load values of the items changes in the first factor between .386-.671, in the second factor between.476-.695, in the third factor between $.423-.881$, in the fourth factor between .514-.721, in the fifth factor between .514-.721. The alpha reliability co-efficient of the subscales of the scale were $.745, .688, .806, .809, .810$; All of the scale is .886 . According to these values, it can be said that the scale is reliable. The KMO value of the scale was calculated as .892 and the Bartlett's test result as 2075 .

In the analysis of the data, SPSS 22.0 statistical package program was used. In the analysis of the data, frequency, percentage and arithmetic mean values were given and comparisons were made with t-test [24]. For variance equality, Levene's test was used. Significance level was taken as .05 , and when necessary, .01 level was also indicated.

\section{Findings}

Findings related to the sub-problem of the research are given in the following headings. Explanations were given in the form of finding tables.

\section{Findings Related to The First Sub-problem}

Table 1. Prospective teachers' use of social media tools

\begin{tabular}{|l|c|c|c|}
\hline Statement & $\mathrm{N}$ & Mean & $\mathrm{Ss}$ \\
\hline 1-I am a blog reader. & 114 & 2.20 & 1.20 \\
\hline 2-I am a blog writer. & 114 & 1.39 & .90 \\
\hline 3-I use Wiki. & 114 & 2.25 & 1.52 \\
\hline 4-I am a Facebook reader. & 114 & 2.90 & 1.49 \\
\hline 5-I am a Facebook writer. & 113 & 1.89 & 1.23 \\
\hline 6-I use Google drive. & 114 & 2.70 & 1.52 \\
\hline 7-I am a Youtube reader. & 114 & 3.99 & 1.12 \\
\hline 8-I am Youtube writer. & 114 & 1.75 & 1.32 \\
\hline 9- I am Twitter reader. & 114 & 3.09 & 1.65 \\
\hline 10- I am Twitter writer. & 114 & 2.33 & 1.64 \\
\hline 11- I am Flicker reader. & 114 & 1.15 & .61 \\
\hline 12- I am Flicker writer. & 114 & 1.05 & .26 \\
\hline 13-I use Picasa. & 114 & 1.25 & .77 \\
\hline 14-I use Skype. & 114 & 2.14 & 1.32 \\
\hline 15-I use Messenger. & 114 & 2.56 & 1.51 \\
\hline 16-I use Secondlife. & 114 & 1.14 & .53 \\
\hline 17-I use Pinterest. & 114 & 1.67 & 1.20 \\
\hline 18- I am Instagram reader. & 114 & 4.01 & 1.41 \\
\hline 19- I am an Instagram writer. & 114 & 3.32 & 1.64 \\
\hline 20-I use Whatsapp. & 114 & 4.74 & .61 \\
\hline 21-I use Snapchat. & 114 & 2.77 & 1.81 \\
\hline
\end{tabular}


The use of social media tools by prospective teachers participating in the research is given in Table 1.

According to Table 1, prospective teachers can use social media tools such as Flicker literacy, Second life, Picasa, Blog authoring, YouTube authoring, Facebook authoring applications with less, Facebook readership, Google drive, Twitter readership, Instagram authoring and Snapchat applications partly, You tube readings and WhatsApp applications mostly.

\section{Findings Related to the Second Sub - problem}

The sub-dimensions for the purpose of using the web technologies of the prospective teachers participating in the research are given in Table 2.

When Table 2 examined, it was found that the use of web technologies by prospective teachers was more frequent than web technologies according to the arithmetic mean scores of daily tasks $(\mathrm{M}=3.83)$, lessons $(\mathrm{M}=3.73)$ and entertainment $(\mathrm{M}=$ level. Prospective teachers' use of web technologies very little at a sub-dimension of business / trade $(M=1.91)$. It is partially utilized for the development $(M=2.77)$ sub-dimension.

Table 2. Purpose of prospective teachers using web technologies

\begin{tabular}{|l|c|c|c|}
\hline $\begin{array}{l}\text { Sub-dimensions for using Web } \\
\text { technologies }\end{array}$ & $\mathrm{N}$ & Mean & $\mathrm{Ss}$ \\
\hline Entertainment & 114 & 3.37 & .96 \\
\hline Business/commerce & 114 & 1.91 & 1.09 \\
\hline Development & 114 & 2.77 & 1.04 \\
\hline Course & 114 & 3.73 & 1.01 \\
\hline Daily works & 114 & 3.83 & .77 \\
\hline
\end{tabular}

\section{Findings Related to the Third Sub Problem}

Table 3 shows whether prospective teachers participating in the survey are differing in their use of web technologies according to their departments.

Table 3. Prospective teachers' intention of using web technologies according to the departments't-test results

\begin{tabular}{|c|c|c|c|c|c|c|c|}
\hline $\begin{array}{l}\text { Sub-dimensions for using } \\
\text { Web technologies }\end{array}$ & Department & $\mathrm{N}$ & Mean & Ss & $\mathrm{T}$ & sd & $\mathrm{p}$ \\
\hline \multirow{2}{*}{ Entertainment } & Primary Sch.Teacher & 61 & 3.18 & .84 & \multirow{2}{*}{-2.288} & \multirow{2}{*}{112} & \multirow{2}{*}{$.024 *$} \\
\hline & CEIT & 53 & 3.59 & 1.04 & & & \\
\hline \multirow{2}{*}{ Business / commerce } & Primary Sch.Teacher & 61 & 1.43 & .72 & \multirow{2}{*}{-5.481} & \multirow{2}{*}{112} & \multirow{2}{*}{$.000^{* *}$} \\
\hline & CITE & 53 & 2.46 & 1.19 & & & \\
\hline \multirow{2}{*}{ Development } & Primary Sch.Teacher & 61 & 2.44 & .95 & \multirow{2}{*}{-3.852} & \multirow{2}{*}{112} & \multirow{2}{*}{$.000^{* *}$} \\
\hline & CITE & 53 & 3.15 & 1.01 & & & \\
\hline \multirow{2}{*}{ Course } & Primary Sch.Teacher & 61 & 3.47 & 1.13 & \multirow{2}{*}{-3.022} & \multirow{2}{*}{112} & \multirow{2}{*}{$.003 *$} \\
\hline & CITE & 53 & 4.02 & .74 & & & \\
\hline \multirow{2}{*}{ Daily Works } & Primary Sch.Teacher & 61 & 3.67 & .75 & \multirow{2}{*}{-2.419} & \multirow{2}{*}{112} & \multirow{2}{*}{$.017 *$} \\
\hline & CITE & 53 & 4.01 & .77 & & & \\
\hline
\end{tabular}

$* \mathrm{p}<0.05$

$* * \mathrm{p}<0.01$

According to Table 3, when prospective teachers use of web technologies according to their intend compared with sections, it is found that there is a meaningful difference between scores in all sub-scales. In the scores of business / trade and development dimensions, it was found that there is a significant difference in favor of the prospective teachers from CITE department $[\mathrm{t}(112)=-5.481, \mathrm{p}<.01],[\mathrm{t}(112)=-3.852, \mathrm{p}<.01]$. There is also a significant difference in the scores of the course, daily work and entertainment sub-dimensions, in favor of the prospective teachers from CITE department $[\mathrm{t}(112)=-3.022, \mathrm{p}<.05],[\mathrm{t}(112)=-2.419, \mathrm{p}<.05],[\mathrm{t}(112)=-2.288, \mathrm{p}<.05]$.

Table 4. Prospective teachers' aims of using web technologies t-test results

\begin{tabular}{|c|c|c|c|c|c|c|c|}
\hline $\begin{array}{l}\text { Sub-dimensions for using } \\
\text { Web technologies }\end{array}$ & Class & $\mathrm{N}$ & Mean & Ss & $\mathrm{t}$ & sd & $\mathrm{p}$ \\
\hline \multirow{2}{*}{ Entertainment } & 1 & 60 & 3.37 & .93 & \multirow{2}{*}{.003} & \multirow{2}{*}{112} & \multirow{2}{*}{.998} \\
\hline & 3 & 54 & 3.37 & .99 & & & \\
\hline \multirow{2}{*}{ Business/ commerce } & 1 & 60 & 1.78 & 1.01 & \multirow{2}{*}{-1.261} & \multirow{2}{*}{112} & \multirow{2}{*}{.210} \\
\hline & 3 & 54 & 2.04 & 1.18 & & & \\
\hline \multirow{2}{*}{ Development } & 1 & 60 & 2.63 & 1.05 & \multirow{2}{*}{-1.511} & \multirow{2}{*}{112} & \multirow{2}{*}{.134} \\
\hline & 3 & 54 & 2.92 & 1.01 & & & \\
\hline \multirow{2}{*}{ Course } & 1 & 60 & 3.51 & .91 & \multirow{2}{*}{-2.488} & \multirow{2}{*}{112} & \multirow{2}{*}{$.014^{*}$} \\
\hline & 3 & 54 & 3.97 & 1.06 & & & \\
\hline \multirow{2}{*}{ Daily Works } & 1 & 60 & 3.71 & .79 & \multirow{2}{*}{-1.819} & \multirow{2}{*}{112} & \multirow{2}{*}{.072} \\
\hline & 3 & 54 & 3.97 & .74 & & & \\
\hline
\end{tabular}

$* \mathrm{p}<0.05$ 


\section{Findings Related to the Fourth Sub Problem}

Table 4 shows whether the prospective teachers participating in the survey are differing in their purpose of using web technologies according to the classes.

When prospective teachers compared for the purpose of using web Technologies in table 4, it was found that there was a meaningful difference only between the scores in the sub-dimension of the course. There is a significant difference in the sub-scale scores in favor of third-year prospective teachers $[t(112)=-2.488, p<.05]$. There was no significant difference between the department scores of primary school and CITE prospective teachers in the other subscales at the class level.

\section{Discussion}

The phenomenon that is very important for everyone in the field of education is social media and the interaction in this area. The increase of social media tools and the use of these tools by individuals increases this importance. At the end of the research, it is striking that social media, which is one of the most important elements of the education field and used by prospective teachers, are YouTube, Instagram and WhatsApp. This situation was the result of a slip from Facebook and Twitter which was used very often before. In a survey which teachers participated at, it was found that approximately half of the teachers $(51 \%)$ used Facebook and very few (6\%) used Twitter [21]. In another research, it was found that the most used social media tool is Instagram (29\%) followed by Snapchat (24\%) and Facebook (23\%) respectively [17]. Again, as a result of a research, it has been revealed that the web technologies mostly used by students are Facebook, blogs, YouTube, Twitter [18]. It is understood here that today's social media is concentrated on Facebook and Instagram. It can be said that these are the most preferred by everyone, that's because Instagram's following, interaction, designing, quickness and easiness are influential.

Social media is a very important platform for communication, collaboration and sharing. This platform is mostly used by social media users. All the individuals spend most of their time in this environment. According to Baran \& Ata [4], more than 1/3 (38\%) of university students always use social media. According to Goh \& Kale [25], more than half of the teachers (58\%) use social sharing tools such as Facebook and Myspace. According to Aydin [26], the most used social media tool by university students is Facebook. According to Tiryakioğlu \& Erzurum [27], most of the teaching staff also benefit from Facebook as social media tool. In another research, it has been revealed that social media tools which are used mostly by teaching staff, teacher and prospective teachers are blog, forum, wiki and social bookmarking [28]. Another study found that social news, networks, music, photo and video sharing were used extensively, whereas, blogs and cloud computing were rarely used [29]. Moreover, it has been revealed that the lessons made by using social media have increased the academic success of the students [30].

When these results are taken into consideration, there are different and similar research findings with some other studies. As a result, social media has become a lifestyle and a field that everyone cannot give up on a daily basis from prospective teachers to academics as a necessity. Therefore, it is necessary to integrate this social media environment and tools in a correct, effective, healthy and successful way in our life, and it is also necessary to learn and teach its positive and negative aspects. Furthermore, by improving the accessibility of web technologies, it can be said that prospective teachers' level of technology usage skills may increase.

Considering social media as literacy from another dimension, it is understood that prospective teachers' dimension of reading is very strong, but the authorship is weak. In this case, it can be argued that it is necessary to emphasize authorship in order to reveal better studies and to produce knowledge and to give education on this subject. In general, to improve engagement it is necessary to make the use of social media tools effective and so, social media usage can have positive results.

As prospective teachers will be in service at schools in future, they must be effective at using social media tools at teaching-learning activities and assessing student success.

It is understood that prospective teachers are to be using web technologies for everyday tasks, lessons and entertainment at sub-dimensions. The dimension that prospective teachers use web technologies the least is the business/trade sub-dimension. For the development sub-dimension, it is medium level. As a result, it can be said that the prospective teachers benefit from web applications for daily work, lessons and entertainment.

It seems that it is not for the purpose of business / trade from applications on the web. The use of Web technologies for personal or professional development is moderate. When the researches on this subject were examined, it was concluded that the purpose of using web tools in Kocadere \& Aşkar [28], research was informing, feedback, discussion and reflective thinking. O'Rourke, Rooney \& Boylan [31], stated that web technologies are used for information sharing.

This reveals that information sharing occurs in a structured way through learning modules, email and announcement tools. Gupta, Singh \& Marwaha [16], emphasized that web technologies should be used for academic purposes and stated that the purpose of using web technologies is for information sharing and personal interaction. In another research, web technologies have been used to integrate lessons [19]. In another research, it was revealed that teachers use web technologies to produce course materials and prepare presentations [21]. In a similar research, prospective teachers have come to the 
conclusion that web technologies are used to reach knowledge [32]. In another research, it was found that the purpose of using social media among university students is to communicate with friends [26].

In another research, web technologies have been found to be used for social communication purposes, such as chatting with friends, commenting on current events or reading news and discussing forums. The interesting result here is that these technologies are useful for social communication, but not for learning [18].

Based on all these research results, it can be said that the general purpose of web technologies is for information sharing, social communication, interaction, chat, discussion and courses. It is understood that these results support daily works (chat, news reading, information sharing, etc.) and course sub-dimensions and research findings.

When the aim of web Technologies usage compared according to prospective teachers' departments a meaningful difference was found. This difference is in favor of the CITE department. However, when the purpose of using web technologies compared between the first and third classes, only a significant difference was found in the course sub-dimension. When these findings are taken into account in terms of departments, it can be said that web technologies are used for different purposes.

In other words, the department of primary school teaching and the CITE department use web technologies for different purposes. In addition, it can be said that when the class level is higher, it is used for teaching purpose. It can be argued that the prospective teachers mostly use of the web sites about their course and field subjects as they get closer to graduation.

Accordingly, when other researches were examined, Keng \& Ching's [33], research found that the statistics department students and the department of computing students differ in the purpose of using web technologies. While the statistics department makes more use of social networks and web search, the department of computing students are benefiting to develop a system. It can be said that this supports the research result.

Kimmons, Clark \& Lim [34], revealed that the purpose of using web technologies differs in the research that compares teacher dimensions, prospective teachers and student dimensions to web technologies. While teacher and prospective teachers use web technology for teaching and research purposes, students benefit from it for learning. This result shows that different groups have changed their aim of use of web technologies. A similar study Gobel \& Kano [35], found that there is a difference in the use of technology among teachers and students. While teachers use web technologies for software purposes, students use their websites for learning purposes.

These results show that the use of web technologies has changed according to the scientific fields and different working groups. It can be said that different departments and working groups are benefitting from the web environment for different purposes. In this case it can be argued that the differences of working areas are natural results. And that these results are similar to research findings.

Taking all these research results into consideration, as Yiğit, Zaim \& Yildirim [36], stated that; web technologies should be considered as a tool that helps to achieve something, not as a goal. It is also necessary to consider the dimensions of professional development, access to resources, integration into training programs, technological resources and support services as factors that play a role in the effective and efficient use of technology. In addition, as the strategy of web technologies, establishment of the award and incentive system and cooperation of each other will play an important role.

According to findings and research results regarding web technologies, social media tools for both teachers and other working groups, have an important technological environment value and great influence. It can be stated that the use of web technologies is realized for various purposes such as sharing, communication and lecture. In addition, the use of web technologies varies according to department/group and class levels.

\section{Conclusions and Recommendations}

The results of this research conducted to reveal the use of social media tools by prospective teachers and the purpose of using web Technologies. The results are explained below.

Prospective teachers use YouTube and Instagram and WhatsApp apps from social media tools in a great deal. Here we are especially noticed the use of WhatsApp with YouTube and Instagram readership. Prospective teachers are more likely to use WhatsApp tools with YouTube and Instagram readership rather than applications such as Facebook and twitter, which were very common in earlier times. Another interesting result is that social media tools are used for readership rather than authorship.

Prospective teachers are understood to be using web technologies for everyday use in daily works, lessons and entertainment at sub-dimensions. The dimension that prospective teachers use web technologies the least is the business/trade sub-dimension. In the development sub-dimension, it is used moderately. As a result, it can be said that the prospective teachers benefits from web applications for daily work, lessons and entertainment. It seems that there is no purpose of doing business / trade from applications on the web. The purpose of personal or professional development is not very strong but moderate.

Compared to prospective teachers who use web Technologies between primary school and CEIT department, there was a significant difference in favor of the CEIT department in all sub-dimensions including 
entertainment, business/trade, development, lessons and daily work. It is possible to reach the result that, the CEIT department prospective teachers learn, utilize and task more web and internet technologies applications in terms of their fields.

When prospective teachers compared at the usage aim of web technologies according to their class levels, there is only a significant difference in the course sub-dimension. At the end of the research, depending on the results of using the social media tools and web technologies of prospective teachers, it is possible to conduct detailed researches such as literacy status, effect, sharing that is related to the use of each social media tool.

Later, studies can be done with prospective teachers in different departments. The situation regarding the use of social media tools at primary, secondary and high levels of education can be revealed. In addition, various comparisons can be designed between different classes and departments at teaching level. With participants in different fields, such as science and literature, economics and business sciences, health and sports sciences, other than prospective teachers may be proposed to design studies related to the use of web technology. In addition to these, researches can be done in a qualitative or mixed model which enables to examine in depth to reach more detailed findings.

\section{REFERENCES}

[1] Naisbitt, J., Naisbitt, N. \& Douglas, P. (2004). Insan ve Teknoloji. İstanbul: CSA Global Yayın Ajansı.

[2] Prensky, M. (2001). Digital natives, digital immigrants. On the Horizon, 9(5), 1-6.

[3] Yükseltürk, E. \& Top, E. (2016). Web 2.0 teknolojilerinin öğretmen eğitiminde kullanımı. Kürşat Çağıltay, Yüksel Göktaş (Ed.), Öğretim Teknolojilerinin Temelleri: Teoriler, Araştırmalar, Eğilimler içinde (ss. 665-680). Ankara: Pegem Akademi.

[4] Baran, B. \& Ata, F. (2013). University students' web 2.0 technologies usage, skill levels and educational usage. Education and Science. 38, 192-208.

[5] Baruah, D. T. (2012). Effectiveness of social media as a tool of communication and its potential for technology enabled connections: a micro-level study. International Journal of Scientific and Research Publications, (2)5, 1-10.

[6] Cann, A. (2011). Social Media: A guide for researchers. UK: Research Information Network.

[7] Darwish, A. \& Lakhtaria, I, K. (2011). The impact of the new web 2.0 technologies in communication, development, and revolutions of societies. Journal of Advances in Information Technology, (2)4, 204-216.

[8] Özmen, F., Aküzüm, C., Sünkür, M. \& Baysal, N. (2012). Sosyal ă sitelerinin eğitsel ortamlardaki işlevselliği. e-Journal of New World Sciences Academy,
NWSA-Education Sciences, 7(2), 496-506.

[9] Dagien, V. \& Kurilovas, E. E. (2010). Web 2.0 technologies and applications in the best practice networks and communities. Informatics in Education, (9)2, 185-197.

[10] Korucu, T. A. (2015). Mesleki ingilizce dersinde dinamik web teknolojileri kullanımının akademik başarıya ve derse karş1 motivasyona etkisi. Ahi Evran Üniversitesi Kırșehir Eğitim Fakültesi Dergisi 16,(3), 243-260.

[11] Relan, A. \& Gillani, B. B. (1997). Web-based instruction and the traditional classroom: Similarities and differences. Badrul H. Khan. (Ed.), Web-Based Instruction içinde (ss. 41-46). New Jersey: Educational Technology Pub.

[12] Baytak, A. (2014). Dünden Bugüne Web Teknolojisi ve Eğitim. Ahmet Baytak (Ed:), Eğitimde Web Teknolojilerinin Kullanımı içinde (ss.1-11). Ankara: Pegem Akademi.

[13] [Horton, W. (2000). Designing Web-Based Training. New York: John Wiley\&Sons, Inc.

[14] Yalın, İ. H. (2015). Öğretim Teknolojileri ve Materyal Geliştirme. Ankara: Nobel Yayın Dağıtım.

[15] Dillon, A. \& Zhu, E. (1997). Designing web-based instruction: A human-computer interaction perspective. Badrul H. Khan. (Ed.), Web-Based Instruction içinde (ss. 221-224). New Jersey: Educational Technology Pub.

[16] Gupta, P., CA., Singh, B. \& Marwaha, T. (2013). Relationship between social media and academic performance in distance education. Universal Journal of Educational Research, 1(3), 185-190.

[17] Knight-McCord, J., Cleary, D., Grant, N., Herron, A., Jumbo, S., Lacey, T., Livingston, T., Robinson, S., Smith, R. \& Emanuel, R. (2016). What social media sites do college students use most? Journal of Undergraduate Ethnic Minority Psychology, 2, 2-26.

[18] Yu, M., Yuen, H. K. A. \& Park, J. (2012). Using web 2.0 technologies: Exploring perspectives of students, teachers and parents. Interactive Technology and Smart Education, 9(4), 204-216.

[19] Göktaş, Y., Yıldırım, Z. \& Yıldırım, S. (2008). Bilişim teknolojilerinin ilköğretim ve ortaöğretim ile bütünleştirilmesindeki anahtarlar: öğretmenlerin algıları ve kullanımları. Hacettepe Üniversitesi Eğitim Fakültesi Dergisi, 34, 127-139.

[20] Baturay, M., Yıldırım, S. \& Daloğlu, A. (2009). Effects of web-based spaced repetition on vocabulary retention of foreign language learners. Eurasian Journal of Educational Research, 9(34), 17-36.

[21] Baydaş, Ö., Gedik, N. \& Göktaş, Y. (2013). Öğretmenlerin bilişim teknolojileri kullanımı: 2005-2011 yıllarının karş1laştırılması. Hacettepe Üniversitesi Eğitim Fakültesi Dergisi, 28(3), 41-54.

[22] Karasar, N. (2005). Bilimsel Araştırma Yöntemleri. Ankara: Nobel Yayın Dağıtım.

[23] Büyüköztürk, Ş., Çakmak, K. E., Akgül, E. Ö., Karadeniz, Ş. \& Demirel, F. (2009). Bilimsel Araştırma Yöntemleri. Ankara: Pegem Akademi. 
[24] Büyüköztürk, Ş. (2002). Sosyal Bilimler İçin Veri Analizi Elkitabı. Ankara: Pegem A Yayıncılık.

[25] Goh, D. \& Kale, U. (2014). The urban-rural gap: Project-based learning with Web 2.0 among west virginian teachers. Tecnology, Pedagogy and Education. 25(3), 355-376.

[26] Aydın, E. İ. (2016). Üniversite öğrencilerinin sosyal medya kullanımları üzerine bir araştırma: Anadolu üniversitesi örneği. Selçuk Üniversitesi Sosyal Bilimler Enstitüsü Dergisi, 35, 373-386.

[27] Tiryakioğlu, F. \& Erzurum, F. (2011). Use of social networks as an education tool. Contemporary Educational Technology, 2(2), 135-150.

[28] Kocadere, A., S. \& Aşkar, P. (2013). Sosyal medya araçlarının katkıları ve kullanım sıklıkları: öğretmenlik uygulaması örneği. Illkögretim Online, 12(4), 1120-1132.

[29] Pritchett, G. C., Pritchett, C. C. \& Wohleb, C. E. (2013). Usage, barriers, and training of web 2.0 technology applications. SRATE Journal, 22(2), 29-38.

[30] Bg Ekici, M. \& Kıyıc1, M. (2012). Sosyal ağların eğitim bağlamında kullanımı. Uşak Üniversitesi Sosyal Bilimler Dergisi, 5(2), 156-167.
[31] O'Rourke, K. C., Rooney, P. \& Boylan, F. (2015). What's the use of a VLE? Irish Journal of Academic Practice, 4(1), $1-21$.

[32] Karaman, M. K. (2010). Öğretmen adaylarınıntv ve internet teknolojilerini kullanma amaç ve beklentilerinin medya okuryazarlığ 1 bağlamında değerlendirilmesi. Ușak Üniversitesi Sosyal Bilimler Dergisi, 3(2), 51-62.

[33] Keng, C. T. \& Ching, K. Y. (2015). A comparison between quantity surveying and information technology students on web application in learning process. Malaysian Online Journal of Educational Technology, 3(1), 1-11.

[34] Kimmons, R., Clark, B. \& Lim, M. (2017). Understanding web activity patterns among teachers, students and teacher candidates. Journal of Computer Assisted Learning. 33, 588-596.

[35] [Gobel, P. \& Kano, M. (2013). Student and teacher use of technology at the university level. IADIS_International Conference on Cognition and Exploratory Learning in Digital Age (CELDA 2013).

[36] Yiğit, G. Y., Zaim, N. \& Yıldırım, S. (2002). Yükseköğretimde öğretim ve idari amaçlı teknoloji kullanımı: Bir durum saptaması. Eğitim ve Bilim, 27(124), 42-51. 